\title{
A study of consumers' general characteristics influence on impulse buying behaviour
}

\section{SHABEERA SULTANA AND K. UMA}

\begin{abstract}
Impulse purchasing is an important phenomenon for researchers in consumer behavior and retailing. The purpose of this paper is to determine the influence of consumers' general characteristics i.e. demographic variables on impulse buying behavior. The paper consists of theoretical and research aspects. The paper encompasses both primary and secondary research. This paper will be useful for marketing practitioners and researchers towards the understanding of the consumer's impetuosity for Fruit juice with respect to their general characteristics. The tools used to test the hypothesis were Percentage analysis, Correlation and Regression analysis. The results showed that demographic factors, such as the age and disposable income are associated with impulse buying behavior of Fruit juice. Disposable income shows much variance on Impulse Buying Behavior.
\end{abstract}

KEY WORDS : Impulse buying, Impulsive buying, Impetuosity, Consumer behavior, Retailing, Fruit juice, Demographic

How to cite this paper : Sultana, Shabeera and Uma, K. (2014). A study of consumers' general characteristics influence on impulse buying behaviour. Internat. J. Com. \& Bus. Manage., 7(2) : 354-362.

\section{MEMBERS OF THE RESEARCH FORUM}

Correspondence to:

SHABEERA SULTANA, Department of Agricultural and Rural

Management, Tamil Nadu Agricultural University, COIMBATORE (T.N.) INDIA Email: shabbi98@yahoo.co.in

Authors' affiliations:

K. UMA, Department of Agricultural and Rural Management, Tamil Nadu Agricultural University, COIMBATORE (T.N.) INDIA 